\title{
UC Davis Fuel Cell, Hydrogen, and Hybrid Vehicle (FCH2V) GATE Center of Excellence
}

\author{
Final Report \\ Submitted on: 29 August, 2012 \\ Submitted by: Paul Erickson, Primary Investigator \\ Institute of Transportation Studies \\ Department of Mechanical and Aerospace Engineering \\ University of California, Davis
}

\section{Introduction}

This is the final report of the UC Davis Fuel Cell, Hydrogen, and Hybrid Vehicle (FCH2V) GATE Center of Excellence which spanned from 2005-2012. The U.S. Department of Energy (DOE) established the Graduate Automotive Technology Education (GATE) Program, to provide a new generation of engineers and scientists with knowledge and skills to create advanced automotive technologies. The UC Davis Fuel Cell, Hydrogen, and Hybrid Vehicle (FCH2V) GATE Center of Excellence established in 2005 is focused on research, education, industrial collaboration and outreach within automotive technology. UC Davis has had two independent GATE centers with separate well-defined objectives and research programs from 1998. The Fuel Cell Center, administered by ITS-Davis, has focused on fuel cell technology. The Hybrid-Electric Vehicle Design Center (HEV Center), administered by the Department of Mechanical and Aeronautical Engineering, has focused on the development of plug-in hybrid technology using internal combustion engines. The merger of these two centers in 2005 has broadened the scope of research and lead to higher visibility of the activity.

UC Davis's existing GATE centers have become the campus's research focal points on fuel cells and hybrid-electric vehicles, and the home for graduate students who are studying advanced automotive technologies. The centers have been highly successful in attracting, training, and placing top-notch students into fuel cell and hybrid programs in both industry and government. 


\section{Letter from the director}

As energy and fuel costs continue to swing wildly, there is an increasing focus on automotive systems and fuel pathways that will suitably provide for our transportation needs with increasing efficiency. This translates into a strong national need for competent engineers with education and background in automotive technology. With this end in mind, we are pleased to report that this project has been productive at the UC Davis Graduate Automotive Technology Education (GATE) Center of Excellence.

The knowledge produced by the program has been published and presented in various conferences and journal publications over the years. Several of the Fellows and the Leadership have journeyed across the nation and the world to present their results and findings to those in the automotive field.

Through the efforts of the UC Davis GATE Center of Excellence the graduate course offerings at UC Davis have been expanded to include a much needed automotive focus. These expansions have taken place in the Mechanical and Aerospace Engineering Department and in the Transportation Technology and Policy graduate group course offerings. This includes new permanent course offerings.

The U.S. DOE sponsored UC Davis GATE Center has thrived and continues to see high demand for both the graduates and knowledge it is producing. Our sincere desire is that through our work we can play a significant part in solving the present national automotive energy challenges.

Overall, the UC Davis GATE Center of Excellence has enjoyed success in its primary goals of supporting curriculum development, supporting graduate student fellowships, allowing students to be placed in industry, disseminating automotive powertrain knowledge, and spurring new research in the advanced automotive powertrain area. While we were unsuccessful for our bid to become a continuing GATE center of excellence in 2011, automotive powertrain research continues in earnest at UCDavis. The director thanks the DOE and the citizens of the United States for supporting this center.

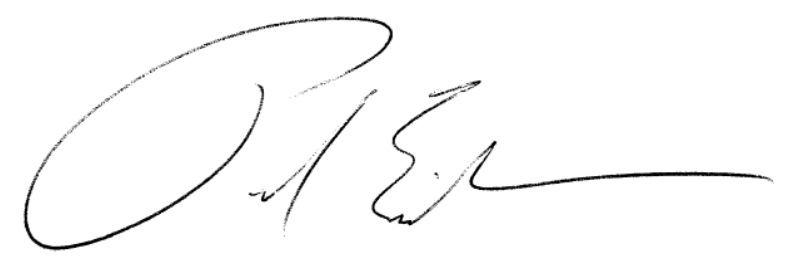

Paul Erickson, Director 


\section{Summary of Work}

We are proud of what the UC Davis GATE program has accomplished in the project period. The most significant accomplishment of the GATE Center has been to support fellowships for students in the automotive field. The bulk of the funds expended went directly to supporting these fellows. The following individuals were supported in whole or in part by GATE funds.

2011 Scott Varnhagen, Zach McCaffrey, Adam Same, Nadia Richards, Shahla Mammadova, 2010 Alexander Allan, William Marin, David Kashevaroff

2009 Doug Saucedo, Jason Greenwood, David Kashevaroff

2008 Andrew Shabashevich, David Vernon, Eddie Jordan, Wayne Leighty

2007 Eddie Jordan, Nils Johnson Brett Williams David Vernon, Jonathan Woolley

2006 David Vernon Brett Williams Bryan Jungers Matt Caldwell

Outgoing fellows have submitted reports outlining their progress to date. These detailed reports are found in previous annual reports.

The director has also given a short summary from each fellows work in previous annual reports submitted to the DOE. These less detailed synopsis was taken from the initial work submitted by the fellows. Titles of the research are given in a later section of this report.

The GATE award has enabled faculty and staff to teach multiple courses over the project period. The most significant of these course offerings enabled by the GATE award are the permanent course offerings: EME 163 (Mechanical Engineering) which teaches the fundamentals of internal combustion engine design and performance; MAE (Mechanical and Aerospace Engineering) 269 which teaches fundamentals of fuel cell technology and hybrid applications; and TTP 210 (Transportation Technology and Policy) which taught those in the Institute of Transportation Studies the fundamental science and engineering concepts at the heart of our current transportation system. The Institute's multidisciplinary education program is geared to graduate students in engineering and the sciences, but also serves undergraduate students, technically sophisticated social science students, and professionals from the fuel cell and hybrid vehicle communities. 


\section{Teaching and Course Improvement}

Through the efforts of the UC Davis GATE Center of Excellence the graduate course offerings at UC Davis have been expanded to include a much needed automotive focus. These expansions have taken place in the Mechanical and Aerospace Engineering Department and in the Transportation Technology and Policy graduate group course offerings. This includes new classes and an expansion of curriculum in the automotive area. New courses include permanenet course offerings of EME 163 (Mechanical Engineering) which teaches the fundamentals of internal combustion engine design and performance; MAE (Mechanical and Aerospace Engineering) 269 which teaches fundamentals of fuel cell technology and hybrid applications; and TTP 210 (Transportation Technology and Policy) which taught those in the Institute of Transportation Studies. Other developments include refinement of these courses. The course EME 163 now has a more refined laboratory portion and dedicates a focus on interfaces between the internal combustion engine and electric motor operation as found in hybrid and in plug-in hybrid operation. New teaching resources in the form of Instruction slides have been developed for the course. Further laboratory work including work with research engines and using a recently acquired Chevy volt from UC Davis fleet services were implemented in this course.

The syllabi for EME 163, MAE 269, and TTP 210 are included below as a reference. It should be noted that each of these courses were initially developed by GATE supported faculty but they they have now become permanent course offerings and are being taught by other non-GATE supported faculty. 
EME 163

\author{
EME 163 Internal Combustion Engines \\ Spring Quarter 2009 \\ T R 9:00-10:20 AM HOAGLD 168 \\ Laboratory F 9-11:50 1230/1208 Bainer Hall
}

Textbook: This book is required and currently at the book store.

Heywood, J. B. Internal Combustion Engine Fundamentals. London: McGraw-Hill, 1988.

References: Pulkrabek, W. W. Engineering Fundamentals of the Internal Combustion Engine. New York: Prentice-Hall, Inc., 1997.

Ferguson, C. R., and A. T. Kirkpatrick. Internal Combustion Engines Applied Thermosciences. 2nd ed. NY: John Wiley \& Sons, Inc., 2001.

Instructor: Paul A. Erickson, Associate Professor of Mechanical and Aeronautical Engineering 2102 Bainer Hall tel. 530-752-5360 lab 530-754-5352 cell 530-383-2642 http://mae.ucdavis.edu/erickson paerickson@ucdavis.edu

Goals: $\quad$ This course is designed to give students an overview of various types of Internal Combustion Engines and their operation. Alternatives to the internal combustion engine as vehicle prime movers are also presented. Students should gain the ability to evaluate the internal combustion engine as well as design and choose components and sub-systems.

Prerequisites by Topic: Thermodynamics

Fluid Mechanics

Topics: SI Engines, CI engines, Rotary engines, Ideal thermodynamic cycles, Combustion, Emissions and control systems, Fuels, Vehicle systems, Alternative power systems.

Labs: $\quad$ Students are required to participate in scheduled laboratory activities. Short memo style lab reports should be written up on the experiments performed and appropriate lab notebooks should be kept by the students.

Grading: All Assignments Exams and laboratory activities must be completed to receive a passing grade. Late assignments are given a penalty of $25 \%$ per day.

2 Tests (30\% each) Grade Weight

Homework Assignments 20\%

Lab Reports

$20 \%$ 


\section{TAs and Group Leaders:}

There is one TA responsible for laboratory safety, instruction and grading this is Nurun Nargis nnnargis@ucdavis.edu You will also be assigned into a Lab Group with a group leader as designated by Professor Erickson.

EME 163 Internal Combustion Engines Tentative Class Schedule (Spring Quarter 2009)

\begin{tabular}{|c|c|c|c|}
\hline Week & Date & Scheduled Activity/Topic & Assignments \\
\hline \multirow[t]{2}{*}{1} & $\overline{3 / 31}$ & Introduction Thermo Review & 1. Thermo Review due 4/7 \\
\hline & $4 / 2$ & Engine Terminology & $\begin{array}{l}\text { Read Text Laboratory } \\
\text { Introduction }\end{array}$ \\
\hline \multirow[t]{2}{*}{2} & $4 / 7$ & SI Engines ideal & \multirow{2}{*}{$\begin{array}{l}\text { 2. Terminology due } 4 / 14 \\
\text { Laboratory (Engine geometry) }\end{array}$} \\
\hline & $4 / 9$ & SI Engines real & \\
\hline \multirow[t]{2}{*}{3} & $4 / 14$ & 2 stroke SI & \multirow{2}{*}{$\begin{array}{l}\text { 3. Heywood Chapters } 1,2,4,5 \\
\text { Laboratory } 1208 \text { Dyno testing }\end{array}$} \\
\hline & $4 / 16$ & CI Engines ideal & \\
\hline \multirow[t]{2}{*}{4} & $4 / 21$ & CI engines real & \multirow{2}{*}{$\begin{array}{l}\text { 4. Heywood Chapters } 3,6 \\
\text { Laboratory } 1208 \text { Dyno testing }\end{array}$} \\
\hline & $4 / 23$ & Combustion & \\
\hline \multirow[t]{2}{*}{5} & $4 / 28$ & Rotary Engines and Midterm Review & \multirow{2}{*}{$\begin{array}{l}\text { 5. No Homework or Lab } \\
\text { Study for Midterm }\end{array}$} \\
\hline & $4 / 30$ & Midterm Exam & \\
\hline \multirow[t]{2}{*}{6} & $5 / 5$ & Power Boosting & 6. Heywood Chapters 9,10 \\
\hline & $5 / 7$ & Vehicle Systems (Parasitic and Aux) & Laboratory engine reassembly \\
\hline \multirow[t]{2}{*}{7} & $5 / 12$ & Vehicle Systems & 7. Heywood Chapters 12,13 \\
\hline & $5 / 14$ & Lubrication systems & Laboratory engine reassembly \\
\hline \multirow[t]{2}{*}{8} & $5 / 19$ & Fuel Delivery systems & 8. Heywood Chapter $7,8,15$ \\
\hline & $5 / 21$ & Fuels & Laboratory TBA \\
\hline \multirow[t]{2}{*}{9} & $5 / 26$ & Emissions and Control systems & \multirow{2}{*}{$\begin{array}{l}\text { 9. Modeling Project Due 6/4 } \\
\text { Laboratory Electric Motors }\end{array}$} \\
\hline & $5 / 28$ & Hybrids & \\
\hline \multirow[t]{2}{*}{10} & $6 / 2$ & Alternatives, bifueling fuel cells, turbines & \multirow{3}{*}{$\begin{array}{l}\text { Modeling Project (continued) } \\
\text { Study for Final Exam }\end{array}$} \\
\hline & $6 / 4$ & Upstream Fuel Processes LCA Review & \\
\hline Final & $6 / 8$ & Monday Exam 10:30-12:30 & \\
\hline
\end{tabular}

EME 163 Internal Combustion Engines Tentative Lab Schedule (Spring Quarter 2009):

\begin{tabular}{|l|l|l|l|}
\hline Week & $\underline{\text { Date }}$ & Activity & $\underline{\text { Location }}$ \\
\hline 1 & F 4/3 & Introduce Small Engines test engines & 1230 Bainer \\
\hline 2 & F 4/10 & Pull apart and Document Small Engines & 1230 Bainer \\
\hline 3 & F 4/17 & IC Dyno Testing (1 $1^{\text {st }}$ group) & 1208 Bainer \\
\hline 4 & F 4/24 & Continued IC Dyno Testing (2 $^{\text {nd }}$ group) & 1208 Bainer \\
\hline 5 & F 5/1 & No Lab Midterm Exam & \\
\hline 6 & F 5/8 & Reassemble small IC engine & 1230 Bainer \\
\hline 7 & F 5/15 & Reassemble small IC engine and Test & 1230 Bainer \\
\hline 8 & F 5/22 & TBA & 1230 Bainer \\
\hline 9 & F 5/29 & Test Electric Motors & \\
\hline
\end{tabular}


Syllabus MAE 269

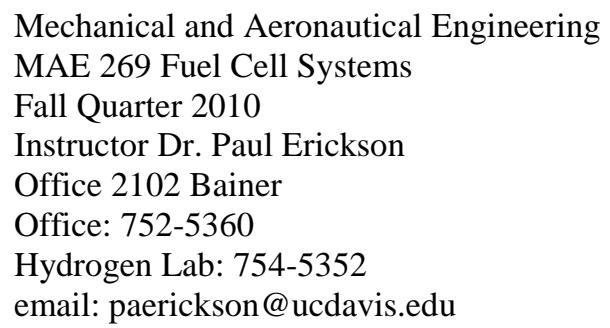

Prerequisites by Topic: Thermodynamics, Fluid Mechanics, Heat Transfer, Physics, Chemistry, Advanced Engineering Mathematics or Equivalent

Text: $\quad$ We will be using Fuel Cell Systems Explained by Larminie and Dicks $2^{\text {nd }}$ Edition 2003 as the primary text

References: $\quad$ Fuel Cell Engines by Matthew Mench

Principles of Fuel Cells by Xianguo Li

Fuel Cell Technology Handbook by Gregor Hoogers

Journal of Power Sources

International Journal of Hydrogen Energy

\section{Course Objective:}

Fuel cell systems is a course designed to prepare students in the basics of electrochemistry and fuel cell engines both as a power supply for vehicle applications or as a stationary energy conversion system. This course should prepare the student for further research in industry or academia. Students participating in this course will gain experience in solving classical problems and application of thermodynamics, physics and chemistry to problem solving in hypothetical situations. Significant literature review will be required and it is expected that laboratory skills will be practiced with the existing fuel cell systems on campus.

\section{Course Assessment:}

Students must be present for all exams and laboratories. All work (Lab Reports, Homework, Exams) must be completed in order to receive a passing grade.

\section{Grading:}

Assignments $\quad 60 \%$

Midterm Exam 20\%

Final Exam $\quad 20 \%$

Homework is due in the professor's box outside of 2102 Bainer by 1:50 PM or in class at 2:10 $\mathrm{PM}$ on the due date. 
Late homework will be accepted at a penalty of $25 \%$ per day.

The Tentative Schedule Follows: (schedule may be changed in class due to the needs of the instructor or the class)

\begin{tabular}{|c|c|c|c|c|}
\hline Week & $\begin{array}{l}\text { Class } \\
\text { Dates }\end{array}$ & Text Book Coverage & Assignment & $\begin{array}{l}\text { Due } \\
\text { Date }\end{array}$ \\
\hline 1 & $9 / 23$ & Chap 1 & $\begin{array}{l}\text { Thermodynamics Review } \\
\text { Assignment A on Website) }\end{array}$ & $9 / 30$ \\
\hline 2 & $\begin{array}{l}9 / 28 \\
9 / 30\end{array}$ & $\begin{array}{l}\text { Chap } 2 \\
\text { Chap } 3\end{array}$ & $\begin{array}{l}\text { Electrochemistry and Maximum } \\
\text { Efficiencies (See Assignment B on } \\
\text { Website) }\end{array}$ & $9 / 7$ \\
\hline 3 & $\begin{array}{l}10 / 5 \\
10 / 7\end{array}$ & Chap 4 & $\begin{array}{l}\text { Lab Report on Fuel Cell Start-Up } \\
\text { Operation, and Shutdown (See } \\
\text { Assignment C on Website) Team Project }\end{array}$ & $10 / 21$ \\
\hline 4 & $\begin{array}{l}10 / 12 \\
10 / 14 \\
\end{array}$ & $\begin{array}{l}\text { Chap } 4 \\
\text { Chap } 5\end{array}$ & $\begin{array}{l}\text { Low Temp Fuel Cells (See Assignment } \\
\text { D on Website) }\end{array}$ & $10 / 28$ \\
\hline 5 & $\begin{array}{l}10 / 19 \\
10 / 21\end{array}$ & $\begin{array}{l}\text { Chap } 6 \\
\text { Chap } 7\end{array}$ & $\begin{array}{l}\text { Low Temp Fuel Cells (See Assignment } \\
\text { E on Website) }\end{array}$ & $11 / 4$ \\
\hline 6 & $\begin{array}{l}10 / 26 \\
10 / 28 \\
\end{array}$ & $\begin{array}{l}\text { Chap } 7 \\
\text { Chap } 10\end{array}$ & $\begin{array}{l}\text { Fuel cells in Stationary systems (See } \\
\text { Assignment F on Website) }\end{array}$ & $11 / 11$ \\
\hline 7 & $\begin{array}{l}11 / 2 \\
11 / 4 \\
\end{array}$ & Exam Chap 1-7 & $\begin{array}{l}\text { Fuel Cells in Vehicle Systems (See } \\
\text { Assignment } \mathrm{G} \text { on Website) }\end{array}$ & $11 / 18$ \\
\hline 8 & $\begin{array}{l}11 / 9 \\
11 / 11\end{array}$ & $\begin{array}{l}\text { Chap } 8 \\
\text { Holiday }\end{array}$ & $\begin{array}{l}\text { Lab Report on Autothermal and Steam } \\
\text { Reformation Start-up Operation and } \\
\text { Shutdown (See Assignment H on } \\
\text { Website) Team Project }\end{array}$ & $11 / 30$ \\
\hline 9 & $\begin{array}{l}11 / 16 \\
11 / 18\end{array}$ & $\begin{array}{l}\text { Chap } 9 \\
\text { Hydrogen systems }\end{array}$ & $\begin{array}{l}\text { Fueling Systems (See Assignment I on } \\
\text { Website) }\end{array}$ & $12 / 2$ \\
\hline 10 & $\begin{array}{l}11 / 23 \\
11 / 25\end{array}$ & $\begin{array}{l}\text { Hydrogen systems } \\
\text { Holiday }\end{array}$ & Fuel cell system modeling & $\begin{array}{l}\text { meet w/ } \\
\text { Prof. E }\end{array}$ \\
\hline 11 & $\begin{array}{l}11 / 30 \\
12 / 2\end{array}$ & $\begin{array}{l}\text { Hydrogen Systems } \\
\text { Review for Final }\end{array}$ & Fuel cell system Modeling & $\begin{array}{l}\text { meet w/ } \\
\text { Prof. E }\end{array}$ \\
\hline
\end{tabular}

The Final exam is scheduled 
Syllabus TTP 210

\title{
Introduction to Transportation Technology
}

\author{
Lecture: $\quad$ Monday and Wednesday, 10:00-11:50 am, Wellman Rm 233 \\ Course Website: $\quad$ Smartsite TTP 210001 W09 \\ Instructor: $\quad$ Nic Lutsey, Ph.D. \\ 2019 Academic Surge \\ Email: nplutsey@ucdavis.edu \\ Office hours: MW 2-3, by appointment
}

\section{Course Overview}

This course explores the fundamental science and engineering concepts at the heart of our current transportation system. We investigate the current dominant automotive technology - the use of petroleum-based fuels in the internal combustion engines as a springboard to study more advanced technologies to reduce the environmental impacts and energy use from automobiles. Our study of the modern automobile will offer an understanding of its basic workings, energy conversion from a fuel to vehicle propulsion, pollution control mechanisms, and factors that contribute to fuel economy. More advanced vehicle technologies, such as plug-in hybrid vehicles, biofuels, fuel cells, will be examined for their potential to reduce vehicle emissions and energy use.

The objective of the course is to provide a proficient understanding of the fundamental automotive technology concepts that relate to policy dilemmas of the day. The course is designed for policy and economics students who are interested in transportation, as well as for engineers who are new to the field of transportation. Basic scientific concepts of physics (e.g., inertia, momentum, energy) and chemistry (e.g., fuel combustion, air pollutant treatment) will be taught as they apply to our study of current and future transportation technologies. The subject matter requires competency in mathematics, but has no prerequisites in physics, chemistry, or engineering disciplines. Upon completion of the course, students will be well grounded in the concepts of vehicles' efficiency, fuel economy, air pollution and greenhouse gas emission impacts - especially as they relate to current news and policy discussions.

\section{Required Textbook}

Energy and the Environment by Ristinen and Kraushaar. 2006. ISBN 0471739898

Energy and the Environment by Fay and Golumb. 2002. ISBN 0195150929

\section{Course Grading}

I. Assignments (20\% total): weekly

II. Two mid-term exams (20\% each): Feb. 2, Feb 25

III. Final Project (15\%): Mar. 10

IV. Final Exam (25\%): Mar 17-21, x:00-x:00pm

\section{Assignments}

Assignments are due in class on the posted due dates. Late assignments will be assessed a $10 \%$ penalty for each day that they are late. 
TTP 210 Class Schedule and Assignments (Winter 2009)

\begin{tabular}{|c|c|c|c|}
\hline Date & Topic & Assignment & Concepts \\
\hline $1 / 5(\mathrm{M})$ & Introduction & & $\begin{array}{l}\text { - History and introduce impacts of transportation on energy } \\
\text { use, environmental impacts } \\
\text { - Policies on vehicles, fuels, emissions }\end{array}$ \\
\hline $1 / 7(\mathrm{~W})$ & $\begin{array}{l}\text { Energy conversion: Forms } \\
\text { of energy }\end{array}$ & & $\begin{array}{l}\text { - Forms of energy (work, heat, chemical, electrical) } \\
\text { - Systems analysis } \\
\text { - Energy conversion, heat engines, } 1^{\text {st }} \text { Law }\end{array}$ \\
\hline $1 / 12(\mathrm{M})$ & $\begin{array}{l}\text { Energy conversion: } \\
\text { Efficiency }\end{array}$ & $\# 1$ due & $\begin{array}{l}\text { - Efficiency } \\
\text { - Entropy, } 2^{\text {nd }} \text { Law }\end{array}$ \\
\hline $1 / 14(\mathrm{~W})$ & $\begin{array}{l}\text { Energy conversion: } \\
\text { Combustion }\end{array}$ & & $\begin{array}{l}\text { - Combustion, chemical reactions, fuel heating values } \\
\text { - Internal combustion engines } \\
\text { - Fuel properties (energy density) }\end{array}$ \\
\hline $1 / 19(\mathrm{M})$ & HOLIDAY: MLK, Jr. Day & & \\
\hline $1 / 21(\mathrm{~W})$ & Energy conversion: Vehicle & $\# 2$ due & $\begin{array}{l}\text { - Vehicle-level energy use, loss } \\
\text { - Vehicle systems (transmission, tires, body) } \\
\text { - Road load equation }\end{array}$ \\
\hline $1 / 26(\mathrm{M})$ & $\begin{array}{l}\text { Air quality: Pollutant } \\
\text { emissions }\end{array}$ & & $\begin{array}{l}\text { - Emission formation } \\
\text { - Real-world emissions } \\
\text { - Emission regulations, testing cycles }\end{array}$ \\
\hline $1 / 28(\mathrm{~W})$ & $\begin{array}{l}\text { Air quality: Pollution } \\
\text { control }\end{array}$ & $\# 3$ due & $\begin{array}{l}\text { - Pollution control technologies (engine controls, catalytic } \\
\text { converter, evaporative emissions, on-board diagnostics) }\end{array}$ \\
\hline $2 / 2(\mathrm{M})$ & MID-TERM \#1 & & \\
\hline $2 / 4(\mathrm{~W})$ & $\begin{array}{l}\text { Energy efficiency: Fuel } \\
\text { economy }\end{array}$ & & $\begin{array}{l}\text { - Measures of efficiency } \\
\text { - Fuel economy policy, historical technology developments } \\
\text { - Impact on fuel use, petroleum independence }\end{array}$ \\
\hline 2/9 (M) & $\begin{array}{l}\text { Energy efficiency: Trade- } \\
\text { offs }\end{array}$ & $\# 4$ due & $\begin{array}{l}\text { - Vehicle characteristics (performance, size) } \\
\text { - Other factors (cost, safety) }\end{array}$ \\
\hline $2 / 11(\mathrm{~W})$ & $\begin{array}{l}\text { Energy efficiency: } \\
\text { Improvement }\end{array}$ & & $\begin{array}{l}\text { - Technologies for efficiency improvement } \\
\text { - Upcoming regulations (federal and state) }\end{array}$ \\
\hline 2/16 (M) & HOLIDAY: President's Day & & \\
\hline $2 / 18(\mathrm{~W})$ & $\begin{array}{l}\text { Greenhouse gas emissions: } \\
\text { Lifecycle analysis }\end{array}$ & \#5 due & $\begin{array}{l}\text { - Life-cycle greenhouse gas emissions } \\
\text { - Technologies for improvement (efficiency, alternative fuels, } \\
\text { refrigerant) }\end{array}$ \\
\hline $2 / 23(\mathrm{M})$ & $\begin{array}{l}\text { Greenhouse gas emissions: } \\
\text { Emerging Policy }\end{array}$ & & $\begin{array}{l}\text { - Policy initiatives, prospects for technology improvement } \\
\text { - Low-carbon fuel standard: targets, alternatives }\end{array}$ \\
\hline $2 / 25(\mathrm{~W})$ & MID-TERM \#2 & & \\
\hline $3 / 1(\mathrm{M})$ & $\begin{array}{l}\text { Vehicle alternatives: Other } \\
\text { fossil fuels }\end{array}$ & \#6 due & $\begin{array}{l}\text { - Technology descriptions, options (Diesel, CNG) } \\
\text { - Potential impacts on criteria pollutants, energy use, } \\
\text { greenhouse gases; pros and cons }\end{array}$ \\
\hline $3 / 3(\mathrm{~W})$ & $\begin{array}{l}\text { Vehicle alternatives: } \\
\text { Biofuels }\end{array}$ & & $\begin{array}{l}\text { - Technology descriptions, options (corn and sugar ethanol, } \\
\text { lignocellulosic, energy crops, waste-derived, algae-derived) } \\
\text { - Potential impacts on criteria pollutants, energy use, } \\
\text { greenhouse gases; pros and cons }\end{array}$ \\
\hline $3 / 8(\mathrm{M})$ & $\begin{array}{l}\text { Vehicle alternatives: } \\
\text { Electricity and hydrogen }\end{array}$ & & $\begin{array}{l}\text { - Technology description, options } \\
\text { - Potential impacts on criteria pollutants, energy use, } \\
\text { greenhouse gases; pros and cons }\end{array}$ \\
\hline $3 / 10(\mathrm{~W})$ & Final presentations & & - TBD \\
\hline $3 / 15(\mathrm{M})$ & Summary & & $\begin{array}{l}\text { - Summary } \\
\text { - Wrap-up, review of course concepts }\end{array}$ \\
\hline $\begin{array}{l}3 / 17- \\
3 / 21\end{array}$ & FINAL EXAM & & \\
\hline
\end{tabular}




\section{TTP 210 Final Project:}

What is the role of transportation technologies in California's climate policy goals?

California has several major initiatives that relate to reducing greenhouse gas emissions. The overarching goals are to reduce California GHG emissions to its 1990 levels by 2020 (AB 32 of 2006), and reduce those emissions by $80 \%$ further by 2050 . Also there are several transportation-specific initiatives in California. What role will transportation technologies have in reducing California's GHG emissions? Which technologies (e.g. efficiency technologies, particular alternative fuels) will play the primary roles in reducing California's transportation emissions by 2020? By 2050? What are the primary advantages of those technologies over the other technologies you studied throughout the course? Write a 3-page paper with your response. You will hand in and present your response in a 10-minute presentation on March 10th. You will be graded by how well you use technology concepts and findings from the course to state your case. 


\section{Research Fellows}

The following individuals have been supported by the GATE Center at UC Davis. Summaries of their research and papers listings can be found in the annual reports previously submitted.

\section{Competitive Award 2010 - 2011}

Scott Varnhagen - The Wankel Engine as a Range Extender for Electric Vehicles: an Experimental and Simulation Study

Zach McCaffrey - Converting Biomass to Fuel Cell Grade Hydrogen via Gasification Adam Same - In-situ Neutron Radiography as a Method of Analysis of Lithium Ion Batteries for Electric Vehicles

\section{Also partially supported in 2011 \\ Nadia Richards - Hydrogen Production through Stratified Reformation: Simulation and Experimental Analysis \\ Shahla Mammadova - Enhanced heat transfer for EGR systems via flow impingement and deflection structures}

Competitive Award 2009 - 2010

Alexander Allan - Characterizing the environmental, economic and energy demand impacts attributable to interactions between electric-drive vehicles and the California electricity grid William Marin - The Effect of Hydrogen on the Diesel cycle David Kashevaroff - An Investigation of Hybrid Mode Reformation for Fuel Cell Applications

\section{Competitive Award 2008 - 2009}

Doug Saucedo - Improving Fuel Economy for Hybrid Electric Vehicles using Electric Turbo-Compounded Internal Combustion Engines through Control System Modeling Jason Greenwood - Utilization of Hydrogen Enrichment to Enhance Combustion and Reduce Emissions of Mixed Alcohols in Ultra-Lean Conditions David Kashevaroff - The Potential of Using Autothermal Reformation With Copperbased Catalysts in Vehicle Applications

\section{Competitive Award 2007 - 2008}

Andrew Shabashevich - Analysis of Waste Heat Recovery from Light-Duty Hybrid Electric Vehicles

David Vernon - Thermal integration and system design for utilizing waste heat and exhaust gases

Eddie Jordan - Hydrogen enriched ethanol combustion in IC engines

Wayne Leighty - Structural Econometric Modeling of the Investment Timing Game in Alaska Oil and Gas Exploration and Development

\section{Competitive Award 2006 - 2007}

Eddie Jordan - Hydrogen enriched ethanol combustion in IC engines

Nils Johnson - Potential for coal-derived hydrogen with CCS 
Brett Williams - Hydrogen-Fuel-Cell Vehicle Adoption: Early California Markets, Vehicle-to-Grid Power, and "Mobile Energy" Innovation

David Vernon - Thermal integration and system design for utilizing waste heat and exhaust gases

Jonathan Woolley - Characterizing the hydrogen conversion trends associated with auto thermal reformation of octane ethanol mixtures.

Competitive Award 2005 - 2006

David Vernon - Hydrogen Enrichment Via Chemical Recuperation to Increase Efficiency and Reduce Emissions in Engines.

Brett Williams - Light-Duty Hydrogen-Fuel-Cell Vehicle Adoption in California: Early Markets, Vehicle-to-Grid Power, and "Mobile Energy" Innovation.

Bryan Jungers - Improving the ITS-Davis Fuel Cell Vehicle Modeling Program (FCVMP): Incorporating Scalability, Transient Effects and Environmental Impact Analysis.

Matt Caldwell - Hydrogen Production from Unpurified bio-derived alcohol mixtures: fundamental investigation of ATR and economic and infrastructure pathway analysis

Over the course of the UC Davis GATE Centers of excellence from 1999-2012 Many MS and Phd Students have been supported as shown below

GATE Center (Year) M.S. Candidates Ph.D. Candidates

1999-2012

Organizations that hired graduates:

UTC Fuel Cells, Ballard, Daimler, General Motors, Ford, Nissan, Toyota, Volkswagen, Agilent, ISE Corp., Aerojet, Electric Power Research Institute (EPRI), United Defense, Eaton, California Fuel Cell Partnership (CaFCP), California State University System, I-Tron, REII, IDE, Oorja Protonics, UC Davis Energy Efficiency Center, Efficient Drivetrain Inc. 


\section{Summary}

Overall, the UC Davis GATE Center of Excellence has enjoyed success in its primary goals of supporting curriculum development, supporting graduate student fellowships, allowing students to be placed in industry, disseminating automotive powertrain knowledge, and spurring new research in the advanced automotive powertrain area. While we were unsuccessful for our bid to become a continuing GATE center of excellence in 2011, automotive powertrain research continues in earnest at UCDavis. The director thanks the DOE and the citizens of the United States for supporting this center. 